\title{
Značilnosti kompozicijskega stavka L. F. Schwerdta s posebnim ozirom na njegove maše
}

Leopold Ferdinand Schwerdt je zapisan v zgodovino slovenske glasbe kot vsestranska glasbena osebnost: skladatelj, dirigent, glasbeni učitelj, cerkveni kapelnik, violončelist. V Ljubljani je deloval več kot petdeset let, verjetno že od 1806. leta pa vse do smrti 1854. Schwerdt danes slovi po svoji Simfoniji v Es-duru in Serenadi, njegova cerkvena dela pa so docela neznana.

Analiza šestih obsežnejših maš je bila osnova magistrske naloge o kompozicijskem stavku Leopolda Ferdinanda Schwerdta. To so: Missa St. Floriani in D, op. 81, Missa in F, op. 83, Missa in B, op. 84, Missa Pastorale, op. 93, Missa pro Resurrectione D.N.J.C. in Es, op. 110, Missa solemnis in A, brez op. Vse skladbe so ohranjene v partih v arhivu na koru ljubljanske stolne cerkve sv. Nikolaja, torej je bilo treba najprej izdelati partiture.

$\mathrm{V}$ uvodu so predstavljeni viri za preučevanje in dosedanje raziskave Schwerdtovega opusa. Razvidno je, da so se raziskovalci večinoma ukvarjali s Schwerdtovo simfonijo ter Serenado.

Prvo poglavje je povzetek značilnosti oblike mašnega ciklusa v 18. stoletju ter opis stanja glasbe v ljubljanski stolnici na prehodu v 19. stoletje. Sledi skladateljev Življenjepis, dopolnjen $\mathrm{z}$ novimi podatki, ter oris Schwerdtove zapuščine $\mathrm{v}$ povezavi z nahajališči.

Osrednji del naloge je namenjen analitičnemu pregledu skladb. Maše so v ločenih poglavjih predstavljene po stavkih. Razpravljanje o posamezi skladbi uvajata shematska pregleda inštrumentacije in osnovnega členjenj stavkov. Sledijo podatki o naslovu, nahajališču ter datacija, na katere s navezuje opis značilnosti zasedbe oziroma inštrumentacije. Razpravljanje kompozicijskih značilnostih posameznih stavkov je sklenjeno s tabelarnim prikazom oblikovnega členjenja, vedno $\mathrm{v}$ povezavi $\mathrm{z}$ menjavami tempa/metruma, besedilom, razmerjem med solisti 
in celotnim orkestrom (soli - tutti) ter spremembami tonalnega centra. Ugotovljene značilnosti so ilustrirane $z$ glasbenimi primeri.

Značilnosti kompozicijskega stavka so povzete $\mathrm{v}$ treh sklopih. Prvi je osredotočen na zasedbo orkestra in rabo inštrumentov. Analiza je pokazala, da sta raba inštrumentov in orkestracija brez dvoma v skladu s priporočili, ki jih je Johann Adolf Scheibe objavil v reviji Critischer musicus, čeprav ne vemo, ali je Schwerdt publikacijo poznal. Drugi sklop obravnava primere tonskega slikanja. Schwerdt je sledil tipiziranim glasbenim vzorcem - melodično gibanje navzgor in/ali visoka glasovna lega spremljajo besede resurrexit, coelum, ascendum, besede descendit, terra in sepultus est gibanje navzdol in nizka lega melodije. Najizrazitejši in strukturalno najbolj značilen primer te baročne tehnike je odlomek Et exspecto resurrectionem mortuorum tretjega stavka Creda. Tretji sklop podaja značilnosti oblike in strukture Schwerdtovih mašnih stavkov. Njegove maše so bile namenjene izvajanju med cerkvenim obredom, zato si nekateri stavki sledijo brez premora (npr. Kyrie, Gloria), drugi (npr. Credo) pa so ločeni z daljšimi deli besedila. Takšna običajna in povsod uveljavljena razporeditev mašnega ordinarija je vplivala na strukturo posameznih stavkov in na makrostrukturo ciklusa, zaradi nje so maše razdeljene v tri večje celote: Kyrie z Glorio, Credo ter Sanctus, Benedictus in Agnus Dei. Vsaka teh celot je bila nato razčlenjena $\mathrm{v}$ zapovrstje med seboj neodvisnih struktur ali $\mathrm{v}$ ciklus stavkov. Prva in zadnja teh struktur/stavkov v posameznih celotah sta bili vedno komponirani $v$ isti tonaliteti in hitrem tempu. Začetno strukturo/stavek je lahko uvedel tudi počasni del, vedno pa je imela vsaka celota tudi vsaj eno strukturo/stavek v počasnem tempu in kontrastni, navadno dominantni tonaliteti. Ta model velja tudi za maše Leopolda Ferdinanda Schwerdta.

Obliko prvega stavka določa tridelnost besedila (Kyrie eleison - Christe eleison Kyrie eleison). Kyrie je pomemben tudi za makrostrukturo skladbe, ker se je njegova glasba ponovila kot sklepni del zadnjega stavka na besedilo Dona nobis pacem.

Za strukturo Schwerdtovih svečanih maš je značilno tudi členjenje dolgih doktrinarnih, za uglasbitev neprimernih besedil Glorie in Creda. Skladatelji so na začetku 18. stoletja besedilo Glorie največkrat delili na enajst manjših sintaktičnih enot, ki so lahko postale samostojne glasbene celote oziroma stavki. To je sicer omogočalo njihovo trdno fakturo, a je močno podaljšalo trajanje maše, ker je praksa uveljavila stalno strukturo posameznih stavkov. Šele razsvetljenske zahteve po preprostosti, ki so spremenile tudi glasbeno oblikovanje, so proti koncu 18. stoletja omejile obseg mašnega cikla. Vpliv besedila na glasbeno fakturo se ni več kazal v makrostrukturi, v zapovrstju samostojnih oblikovnih celot-stavkov, temveč le še v mikrostrukturi, $v$ zapovrstju med seboj odvisnih strukturalnih enot znotraj iste celote, ne da bi se bil zato spremenil način členjenja besedila.

V skladu z opisanim je oblikovan tudi Credo. Dispozicija tem v prvem doktrinarnem delu Creda spominja kdaj pa kdaj na sonatni stavek, sicer je običajno tridelen. Druge glasbeno-tekstovne celote Et incarnatus - Crucifixus je skladatelj namenil solistu oziroma solistom. Tretja sintaktična celota, Et resurrexit, je glasbeno in strukturalno enaka prvemu, doktrinarnemu delu Creda, izjema so le običajne 
tonalne spremembe, značilne za reprizo. Četrti del Creda, Et vitam venturi, ni vedno samostojna celota, vedno pa ima vlogo kode.

Sanctus, najkrajši stavek, je brez izjeme namenjen zboru, ki ga nekajkrat spremlja le godalni orkester. Običajno je oblikovan dvodelno in ima značaj uvoda $\mathrm{k}$ Benedictusu. Ta je navadno oblikovan kot arija za solista ali ansambel solistov, med katero so vedno vpleteni inštrumentalni koncertantni odlomki. Agnus Dei je običajno oblikovan kot tonalno nestabilen niz period $\mathrm{z}$ modulacijami prek molskih tonalitet $\mathrm{v}$ dominanto osnovnega tonskega načina, ki pripravi ponovitev glasbenega gradiva iz Kyrie na besedilo dona nobis pacem.

$\mathrm{V}$ dveh mašah je skladatelj poleg ordinarija uglasbil še dele propriuma: Offertorium v Missai Pastorale, op. 93, ter ofertorij in gradual v maši Pro Resurrectione D.N.J.C., op. 110.

$\mathrm{V}$ osnovi klasicistična faktura Schwerdtovih maš sloni na izrazito baročnem umevanju členjenja in glasbenega upodabljanja besedila ter na orkestrski zvočnosti prve polovice 18. stoletja. Ta dela so značilni primeri cerkvene glasbe, ki skuša izražati in sprejeti spremembe 18. stoletja, kakor so jih uveljavile druge glasbene zvrsti. Občasno, zlasti v spremljavi, tipizirana metrično-ritmična sosledja, nekoliko bidermajerska melodika in samo kdaj pa kdaj kromatizirana harmonija razkrivajo značilen glasbeni jezik takšne usmeritve. Oblikovanje sledi besedilu (dramatične dele poudarja skladatelj predvsem $z$ dinamičnimi učinki), okvirna tridelnost stavkov kaže pregledno zasnovo ter strukturalno preprostost. Na kratko: ustvarjalci maš na prelomu 18. in 19. stoletja so se podrejali uveljavljenim (zastarelim) vzorcem oblikovanja in tudi Schwerdtova dela iz arhiva ljubljanskega stolnega kora niso segla iz tega okvira.

Obranjeno 10. marca 1999 na Filozofski fakulteti Univerze v Ljubljani.

\section{The Characteristics of Compositional Technique of L. F. Schwerdt with a Special Consideration of His Masses}

Leopold Ferdinand Schwerdt is written into the history of Slovene music as an all-round musical personality: composer, conducter, music teacher, church choir conductor, and violoncellist. He worked in Ljubljana for more than fifty years, probably as early 1806 and continuing until his death in 1854. Today Schwerdt is famous for his Symphony in E-flat Major and his Serenade, but as for his ecclesiastical works, they are completely unknown.

An analysis of his six longer masses was the basis for this master's thesis on the compositional technique of Leopold Ferdinand Schwerdt. These masses are: Missa St. Floriani in D, op. 81, Missa in F, op. 83, Missa in B, op. 84, Missa Pastorale, op. 93, Missa pro Resurrectione D.N.J.C. in E-flat, op. 110, Missa solemnis in A, without op. All the compositions are preserved in parts in the archive of the choir of the Ljubljana Cathedral Church of St. Nicholas; hence, it was first necessary to create scores. 


\section{MUZIKOLOŠKI ZBORNIK • MUSICOLOGICAL ANNUAL XXXV}

In the introduction, the sources for the present study and previous research into Schwerdt's opus are presented. It is clear that the researchers have been mostly concerned with Schwerdt's Symphony and Serenade.

The first chapter is a summary of the characteristics of the form of the mass cycle in the 18th century and a description of the state of music at the Ljubljana Cathedral at the turn of the 19th century. This is followed by the composer's biography, updated with new information, as well as an outline of Schwerdt's legacy in connection with the sites where it was found.

The central part of the work is dedicated to the analytical survey of his compositions. The masses are presented in the separate chapters according to movements. The discussion of an individual composition is introducted by two schematic surveys of the instrumentation and the basic structure of the movement. This is followed by data concerning the title, the location of the work, and the dating of it, all this data being linked to a description of the characteristics of the setting and the instrumentation.

The discussion of the compositional characteristics of the individual movements is concluded with a tabulated account of formal structuring, always in connection to changes in the tempo/metre, the text, the relation between the soloists and the entire orchestra (solitutti), and changes of the tonal centre. The ascertained characteristics are illustrated with musical examples.

The characteristics of the compositional technique are summarized in three parts. The first one is focused on the instrumentation and the use of the instruments. This analysis has shown that the use of the instruments and the orchestration are doubtlessly in accord with the recommendations suggested by Johann Adolf Scheibe in the periodical Critischer musicus, although we do not know whether Schwerdt was acquainted with the publication. The second part deals with examples of tone painting. Schwerdt followed typical musical patterns - upward melodic movement and/or high vocal placement accompany the words resurrexit, coelum, ascendum, whereas, the words descendit, terra in sepultus est are set in a downward movement and a low melodic placement. The most distinctive and structurally the most characteristic example of this baroque technique is the fragment Et expecto resurrectionem mortuorum of the third section of the Credo. The third part presents the characteristics of the form and structure of Schwerdt's mass movements. His masses were intended to be performed at an ecclesiastical rite, therefore some movements follow without a break (e.g. Kyrie, Gloria); as for others (e.g. Credo), they are separated by longer sections of text. The usual and universally spread scheme of the ordinary of the mass influenced the structure of the individual movements as well as the macrostructure of the entire cycle; because of this, masses are divided into three larger units: Kyrie with Gloria, Credo and Sanctus, Benedictus and Agnus Dei. Each of these units was then taken apart and then put into a succession of independent structures or into a cycle of movements. The first and last of these structures/movements in a particular unit were always composed in the same tonality and fast tempo. The opening structure/movement could have been also introduced by a slower part, but each of the units always had at least one structure/movement in a slow tempo and a contrasting, usually dominant tonality. This model also applies to the masses of Leopold Ferdinand Schwerdt.

The form of the first movement is determined by the three-part structure of the text (Kyrie eleison - Christe eleison - Kyrie eleison). This first movement is also important for the macrostructure of the composition because the music repeats itself as the final part of the last movement for the text Dona nobis pacem. 


\section{MUZIKOLOŠKI ZBORNIK • MUSICOLOGICAL ANNUAL XXXV}

Characteristic of the structure of Schwerdt's solemn masses is also a dividing of the long doctrinal texts of the Gloria and Credo, which were awkward for a musical setting. At the beginning of the 18th century, composers most often divided the text of the Gloria in eleven shorter syntactic units, which then could become individual musical sections or movements. Although this enabled their stable texture, it also prolonged the duration of the mass because the praxis enforced the permanence of the structure of individual movements. It was only the Age of Enlightenment's demands for simplicity that changed the musical forms also so that towards the end of the 18th century limits to the duration of the mass cycle were set. The influence of the text on the musical structure was no longer reflected in the macrostructure, that is, in the succession of the independent formational units/movements, but it only continued to be reflected in the microstructure, in the succession of the structural sections dependent on each other within the same unit without changing the manner of dividing the text.

The Credo is also structured in accord with the above description. The disposition of the themes in the first doctrinal part of the Credo is at times reminiscent of a sonata movement, which customarily has three parts. The composer intended the other musical-textual units Et incarnatus - Crucifixus for a soloist or soloists. The third syntactic section, Et resurrexit, is musically and structurally identical to the first doctrinal part of the Credo, the exceptions being only tonal changes characteristic of the recapitulation. The fourth part of the Credo, Et vitam venturi, is not always an independent unit, but it always has the role of a coda.

The Sanctus, the shortest movement, is without exception intended for the choir, which at times is accompanied by a string orchestra. It is usually composed of two parts and acts as an introduction to the Benedictus. The Benedictus is customarily designed as an aria for a soloist or an ensemble of soloists and within which instrumental concertante fragments are interweaved. The Agnus Dei is usually designed as a tonally unstable series of periods with modulations through minor tonalities into the dominant of the fundamental tonic key, which prepares for the repetition of musical material from the Kyrie for the text dona nobis pacem.

In two masses, the composer has, besides the ordinary, set parts of the proper: the Offertorium in Missai Pastorale, op. 93 and the offertory and gradual in the mass Pro Resurrectione D. N. J. C., op. 110.

The basically classical texture of Schwerdt's masses is based on a distinctly baroque understanding of the division and musical interpretation of the text as well as on the orchestral sonority of the first half of the 18th century. These works are characteristic examples of church music which was trying to express and accept the changes of the 18th century, just as these changes were employed in the other musical foms. At times, especially in accompaniments, typified metric-rhythmic sequences, slightly Biedermeieresque melodic patterns, and only occasional chromatic harmony reveal the characteristic musical language of such an orientation. The form follows the text (the composer accentuates dramatic parts by use of dynamic effects), the three-part frame of the movements manifests a clear scheme and structural simplicity. Briefly: the composers of masses at the turn of the 18th century submitted themselves to the generally employed (outdated) patterns of form and also Schwerdt's works from the archive of the Ljubljana cathedral choir did not exceed this frame.

Defended on March 10, 1999, Philosophical Faculty, University of Ljubljana. 